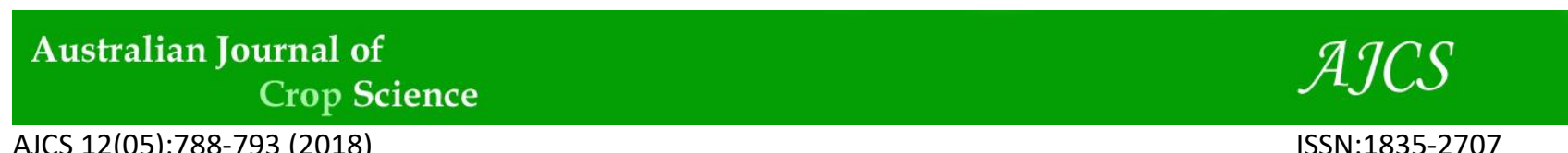

AJCS 12(05):788-793 (2018)

ISSN:1835-2707

doi: $10.21475 /$ ajcs.18.12.05.PNE932

\title{
Salicylic acid (SA) addition influences postharvest quality of 'Jubileu' peaches (Prunus persica)
}

\author{
Marines Batalha Moreno Kirinus*1, Caroline Farias Barreto', Pricila Santos da Silva², Paulo Celso de Mello \\ Farias ${ }^{1}$, Marcelo Barbosa Malgarim ${ }^{1}$
}

\author{
'Departamento de Fitotecnia - Universidade Federal de Pelotas (UFPel) - Faculdade de Agronomia Eliseu Maciel \\ (FAEM) - Av. Eliseu Maciel, s/n, 96010-900, Capão do Leão-RS, Brazil \\ ${ }^{2}$ Departamento de Produção Vegetal - Universidade do Estado de Santa Catarina (UDESC) - Av. Luís de Camões, \\ 2090 - Conta Dinheiro, 88520-000, Lages-SC, Brazil
}

*Corresponding autho: marinesfaem@gmail.com

\begin{abstract}
The SA organic elicitor is an alternative to extend the useful life of fruits by inducing the defenses of the plant and decreasing fruit rot. This study aimed at evaluating not only the effects of SA applied after the harvest in the cold storage period, but also the marketing simulation of the maintenance of physicochemical characteristics of 'Jubileu' peaches. The experimental design was thoroughly randomized in a double factorial scheme. Fruits were picked at proper maturity, in agreement with the maturity index. In the laboratory, they were submitted to SA doses of $0,2,4$ and $6 \mathrm{mM}$ and, then, kept in a cold room at $1 \pm 1$ 으, at $90 \pm 5 \%$,for 7 , 14 and 21 days. Afterwards, a 3-day shelf life was simulated at $25 \pm 50 \mathrm{C}$. Characteristics under evaluation were fruit mass loss, firmness, color, solids/acidity and rot. Predictive points of the variables under analysis were observed because they are important to determine the interaction between time and dose. Regarding parameters of solids/acidity, the predictive point ranged from 14.88 to 3.51 SA in 11.5 days. SA application decreased mass loss in 11.1 days at2.16 mM and firmness, in 11.3 days at doses of $2.75 \mathrm{mM}$. The predictive point of rot incidence was 5.96 at3.97 mM SA in 8.48 days whereas the one of color brightness was 68.32 at $1.25 \mathrm{mM}$ SA in 19.7 days. Finally, the one of hue was 87.92 at $2.81 \mathrm{mM}$ SA in 15.3 days. SA was efficient to keep the general quality of 'Jubileu' peaches.
\end{abstract}

Keywords: Cold storage; Elicitors; Fruit; Prunus persica; Rot control;

Abbreviations: SA_Salicylic Acid; SS_Soluble Solids; TA_Titratable acidity; L*_Brightness; a*_Red / green coordinate; b*_yellow/ blue coordinate; ANOVA_Analysis of variance; Ratio_Result of the SS/TA relation.

Introduction

Peach (Prunus persica (L.) Bastch) is a species with high economic importance among stone fruits. Both peach and nectarine havea mean world production of 21 million tons. Brazil's mean yield is 232 tons in 20 thousand hectares, which means that its productivity is low by comparison with other countries. As a result, it is placed thirteenth in the world ranking (FAO, 2016). Rio Grande do Sul state, in the extreme south of Brazil, is the largest producer of stone fruits, importer and exporter of the culture (Oliveira et al., 2011), and responsible for around $60 \%$ of the national production (Fachinello et al., 2011). It is followed by São Paulo (17\%), Minas Gerais (10\%), Paraná (7\%) and Santa Catarina (6\%) (Madail, 2014). Peach trees, which are native to central China, belong to the family Rosacea and are one of the main fruit trees cultivated in regions with temperate and subtropical climates, besides being a stone fruit plant with high economic value (Madail, 2014).

However, since peaches are fruits with a short growing season and very perishable, they must be properly stored to avoid losses. Therefore, cold is used, but it cannot reach the desired efficiency alone. Peaches also require chemical products which are applied before and after harvest so as to increase the time period fruits can be made available to consumers. Thus, techniques to decrease metabolic activities and increase life of peaches after harvest must bestudied. Current standards require chemical products to be biologically safe, a fact that leads to the application of elicitors, which are alternative sources to replace chemical fungicides (Serrano et al., 2013).

Salicylic acid, an elicitor which has a comprehensive role as signaling molecule in plants, mainly in the defense against pathogenic agents (hypersensitivity response), is a trigger molecule that is key to express several ways of resistance (Asghari and Aghdam 2010). Its capacity of defense against pathogens, by means of many biochemical and physiological reactions, trigger the production of several secondary metabolites (Hall et al., 2011).

Elicitors have been used for increasing fruit storage time (Hadian-Deljou et al., 2017). The mechanism of plant defense is activated by systemic signaling, i. e., SA, in this case, which changes the biosynthesis of secondary metabolites effectively in the postharvestof peaches 
(Khademi and Ershadi, 2013), blackberries (Borsatti et al., 2015), strawberries (Ghaderi, et al., 2015; Salari et al, 2012), passion fruits (Weber et al., 2012) and apples (Quaglia et al., 2011). SA is a product that has been considered safe for consumers (Supapvanich and Promyou, 2013) because it is a natural component of fruits (Belitz and Grosch, 2004).

Since the literature describes SA as a compound that triggers plant defenses and delays fruit senescence, this study aimed at evaluating the effects of SA applied to postharvestin the cold storage period along with the marketing simulation of the maintenance of physicochemical characteristics of 'Jubileu' peaches.

\section{Results}

A summary of the analysis of variance (ANOVA) of the models is shown in Table 1.The ANOVA of the regression models showed that the resulting models were significant ( $p$ $<0.05$ ) and did not have any significant adjustment failure. Therefore, these models may be used for describing effects of the selected independent variables (solids/acidity, mass loss, firmness, rot percentage, $L *$ and hue). The linear effect of the applied dose and storage time of SA and its interactions were observed in all variables under analysis ( $p$ $<0.0001$ ), as shown in Table 1 . Regarding the quadratic effect of the applied dose and storage time of SA, interaction was found among the following variables: relation ( $p$ $<0.0103)$, firmness $(p<0.0010)$, rot percentage $(p<0,0005)$ and hue $(p<0.0076)$. However, there was no interaction between mass loss $(p<0.0588)$ and luminosity $(p<0.0531)$, as shown in Table 1.

Lack of adjustment was not significant in the following variables: relation $(p<0.27)$, mass loss $(p<0.89)$, firmness ( $p$ $<0.17)$,rot percentage $(p<0.40), L^{*}(p<0.61)$ and hue ( $p$ $<0.43$ ). It shows that response surface equations for SA doses and storage periods describe the data adequately (Table 1 and Figures 1,2,3,4,5 and 6).

Data on the ratio of solids/acidity adjusted well to the established regression model $(F=20.01 ; p<0.0001) ; R^{2}$ was 0.70 and $R^{2}$ adj was 0.67 , as shown in Figure 1 . Throughout the variable optimization process, the roots of the auxiliary equations were positive and negative in their magnitudes, showing the saddle point as a stationary point. The predictive value of the relation in this point ranged from 14.88 to $3.51 \mathrm{mM} \mathrm{SA}$ in 11.5 days.

Data on rot adjusted to the established regression model adequately $(F=20.74 ; p<0.0001) ; R^{2}$ was 0.71 and $R^{2}$ adj was 0.68 ,as shown in Figure 2 . Throughout the variable optimization process, the roots of the auxiliary equation got positive values, showing that the stationary point is minimum. The predictive value of the stationary rot was $5.96 \%$, which was reached with 3.97 mM SA in 8.48 days.

Data on firmness adjusted to the established regression model adequately $(F=11.92 ; p<0.0001) ; R^{2}$ was 0.79 and $\mathrm{R}^{2}$ adj was 0.77 , as shown in Figure 3 . Throughout the variable optimization process, the roots of the auxiliary equations were positive and negative in their magnitudes, showing the saddle point as a stationary point. The predictive value in this point was $11.8 \mathrm{~N}$, which was reached with $2.75 \mathrm{mM}$ SA in 11.3 days.

Data on mass loss adjusted to the established regression model adequately $(F=31.23 ; p=<0.0001) ; R^{2}$ was 0.79 and $\mathrm{R}^{2}$ adj was 0.76 , as shown in Figure 4 . Throughout the variable optimization process, the roots of the auxiliary equations were positive and negative in their magnitudes, showing the saddle point as a stationary point. The predictive value of mass loss in the stationary point was $12.6 \%$, which was reached with $2.16 \mathrm{mM}$ SA in 11.1 days.

Data on peach luminosity $\left(\mathrm{L}^{*}\right)$ adjusted to the established regression model adequately $(F=7.66 ; p<0.0001) ; R^{2}$ was 0.67 and $R^{2}$ adj was 0.65 , as shown in Figure 5. Throughout the variable optimization process, the roots of the auxiliary equations were positive and negative in their magnitudes, showing the saddle point as a stationary point. In this situation, the predictive value was 68.32 , which was reached with $1.25 \mathrm{mM}$ SA in 19.7 days.

Data on hue adjusted to the established regression model adequately $(F=9.50 ; p<0.0001) ; R^{2}$ was 0.63 and $R^{2}$ adj was 0.57 , as shown in Figure 6 . Throughout the variable optimization process, the roots of the auxiliary equations were positive and negative in their magnitudes, showing the saddle point as a stationary point. In this situation, the predictive value was 87.92 , which was reached with 2.81 mM SA in 15.3 days

\section{Discussion}

Previous studies of SA application showed enzyme degradation which mitigates fruit softening and effectively reduces the respiratory metabolism of peaches, with weight loss control (Asghari and Aghdam, 2010), as observed in the experiment reported by this study, in which fruit firmness and mass were kept. However, fruit mass loss is related to water loss by fruit transpiration and respiration (Brackmann et al., 2007). Studies of pulp firmness of 'Maciel' and 'Chimarrita' peaches with different rootstocks (Comiotto et al., 2012) found results that are similar to the ones of this experiment, i. e., fruits treated with SA kept their firmness. SA activated the systemic defense of 'Jubileu' peachesand also controlled rotin peaches. Since SA application led to postharvest rot control (Yang et al., 2011), it became a viable alternative to control pathogens naturally.

SA application reduces soluble solids, which means levels of reducing sugars, i. e., starch maturation and degradation are stabilized. It is beneficial to reduce weight loss in 'Elberta' peaches stored for 42 days at $0^{\circ} \mathrm{C}$ (Khademi and Ershadi, 2013), whereas 'Jubileu" peaches stored at $1 \pm 1$ o C undergo the effect of reduction in weight loss in 11.1 days, since this cultivar has more perishable fruits. 'Flordaking' peaches (Tareen et al., 2012), with a dose of $1.5 \mathrm{mM}$, kept their brightness up to 14 days of storage, besides more significant hue values, at the same dose. Fruits treated with SA had better hue than non-treated ones. This parameter is very useful to determine the fruit ripening degree (Infante et al., 2011).

In 'Jubileu' peaches (Tareen et al., 2012), a dose of 2.74 $\mathrm{mM}$ kept physical and chemical characteristics and mitigated rotfor 12.89 days in a cold room at $1 \pm 1^{\circ} \mathrm{C}$ and at $90 \pm 5 \%$ relative humidity.

In general, not only the physical and chemical quality of fruits may be kept but also rot can be mitigated by SA application. It should be highlighted that SA application generates increase in the bioactive compounds of fruits, such as compound phenomena, flavonoids, anthocyanins through the activation of the enzyme phenylalanine 
Table 1 .ANOVA results of the regression equation for solids/acidity, mass loss, firmness, rot percentage, $L^{*}$ and hue with salicylic acid doses $(0,2,4$ and $6 \mathrm{mM})$ applied postharvest, storage periods $\left(7,14\right.$ and 21 days at $\left.1 \pm 1^{\circ} \mathrm{C}\right)$ and a 3-day useful life simulation.UFPel, Pelotas, RS, Brazil.

\begin{tabular}{|c|c|c|c|c|c|}
\hline Responses & Source & SS & MS & $F$ value & $\operatorname{Pr}>F$ \\
\hline \multirow{6}{*}{ Ratio } & Linear & 263.23 & & 44.90 & $<0.0001$ \\
\hline & Quadratic & 29.98 & & 5.11 & 0.0103 \\
\hline & Cross-product & 10.15 & & 3.05 & 0.0421 \\
\hline & Total model & 303.36 & & 20.01 & $<0.0001$ \\
\hline & Lack of fit & 38.42 & 6.40 & 2.72 & 0.27 \\
\hline & Pure error & 84.70 & 2.35 & & \\
\hline \multirow{6}{*}{ Mass loss } & Linear & 520.12 & & 73.48 & $<0.0001$ \\
\hline & Quadratic & 21.48 & & 3.03 & 0.0588 \\
\hline & Cross-product & 11.02 & & 3.11 & 0.0499 \\
\hline & Total model & 552.62 & & 31.23 & $<0.0001$ \\
\hline & Lack of fit & 8.60 & 1.43 & 0.37 & 0.89 \\
\hline & Pure error & 140.05 & 3.89 & & \\
\hline \multirow{6}{*}{ Firmness } & Linear & 141.70 & & 21.25 & $<0.0001$ \\
\hline & Quadratic & 54.87 & & 8.23 & 0.0010 \\
\hline & Cross-product & 12.16 & & 3.65 & 0.0423 \\
\hline & Total model & 208.73 & & 11.92 & $<0.0001$ \\
\hline & Lack of fit & 29.93 & 4.99 & 1.64 & 0.17 \\
\hline & Pure error & 106.78 & 3.05 & & \\
\hline \multirow{6}{*}{ Rot percentage } & Linear & 2552.60 & & 42.64 & $<0.0001$ \\
\hline & Quadratic & 542.19 & & 9.06 & 0.0005 \\
\hline & Cross-product & 10.00 & & 3.33 & 0.0564 \\
\hline & Total model & 3104.79 & & 20.74 & $<0.0001$ \\
\hline & Lack of fit & 188.44 & 31.41 & 1.06 & 0.40 \\
\hline & Pure error & 1068.75 & 29.69 & & \\
\hline \multirow{6}{*}{$L^{*}$} & Linear & 44.36 & & 18.80 & $<0.0001$ \\
\hline & Quadratic & 29.83 & & 5.04 & 0.0531 \\
\hline & Cross-product & 10.74 & & 3.63 & 0.0452 \\
\hline & Total model & 84.93 & & 7.66 & $<0.0001$ \\
\hline & Lack of fit & 5.56 & 0.93 & 0.76 & 0.61 \\
\hline & Pure error & 44.00 & 1.22 & & \\
\hline \multirow{6}{*}{ Hue } & Linear & 124.33 & & 17.34 & $<0.0001$ \\
\hline & Quadratic & 39.37 & & 5.49 & 0.0076 \\
\hline & Cross-product & 16.54 & & 3.82 & 0.0180 \\
\hline & Total model & 180.24 & & 9.50 & $<0.0001$ \\
\hline & Lack of fit & 59.22 & 9.87 & 3.89 & 0.43 \\
\hline & Pure error & 91.37 & 2.54 & & \\
\hline
\end{tabular}

SS, sum of squares; MS, mean square.

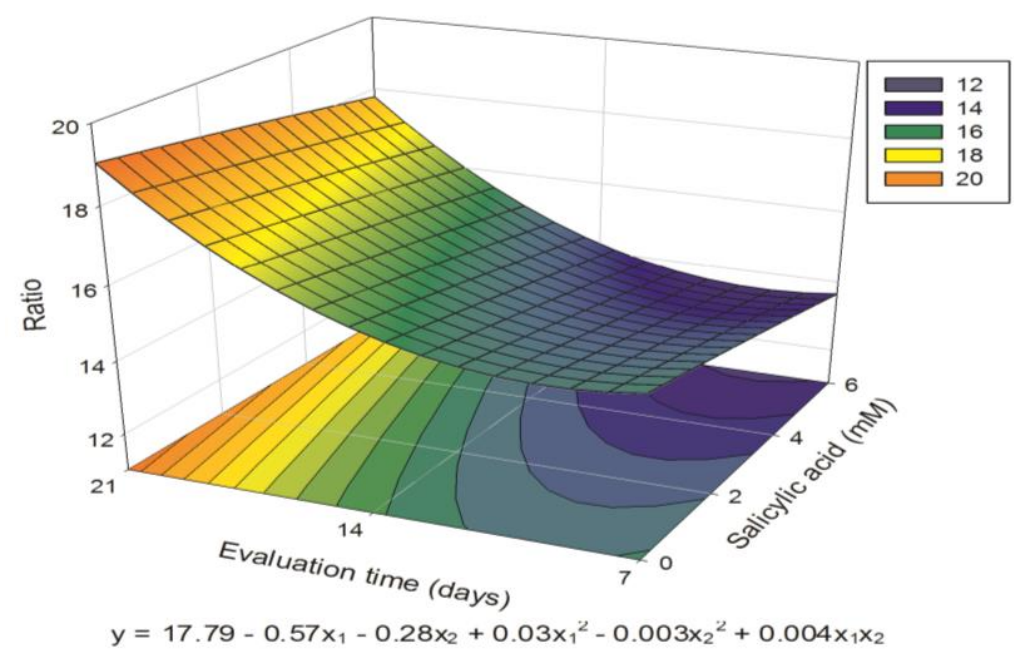

Fig 1. Graph of response surface of the relation between soluble solids and titratable acidity (Ratio) in relation to salicylic acid doses $(0,2,4$ and $6 \mathrm{mM})$ applied postharvest, storage periods $\left(7,14\right.$ and 21 days at $\left.1 \pm 1^{\circ} \mathrm{C}\right)$ and a 3 -day shelf life simulation $\left(25 \pm 5^{\circ}\right.$ C).UFPel, Pelotas, RS, Brazil. 


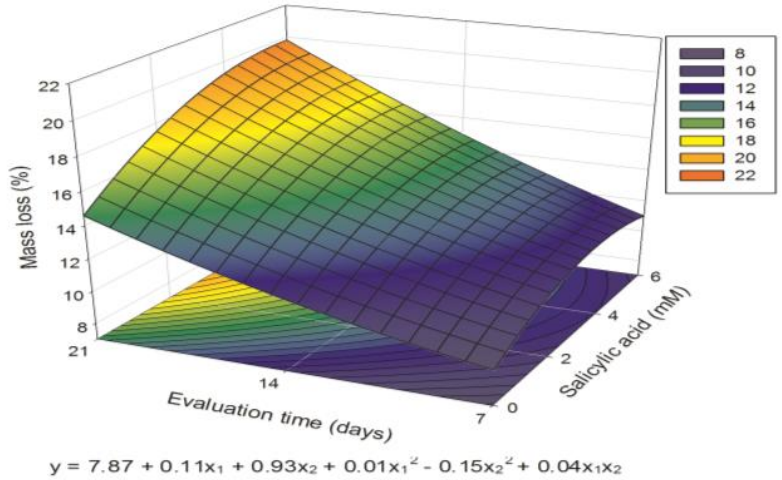

Fig 2. Graph of response surface of the relation among fresh mass loss, salicylic acid doses $(0,2,4$ and $6 \mathrm{mM})$ applied postharvest, storage periods $\left(7,14\right.$ and 21 days at $\left.1 \pm 1^{\circ} \mathrm{C}\right)$ and a 3 -day shelf life simulation ( $\left.25 \pm 5^{\circ} \mathrm{C}\right)$.UFPel, Pelotas, RS, Brazil.

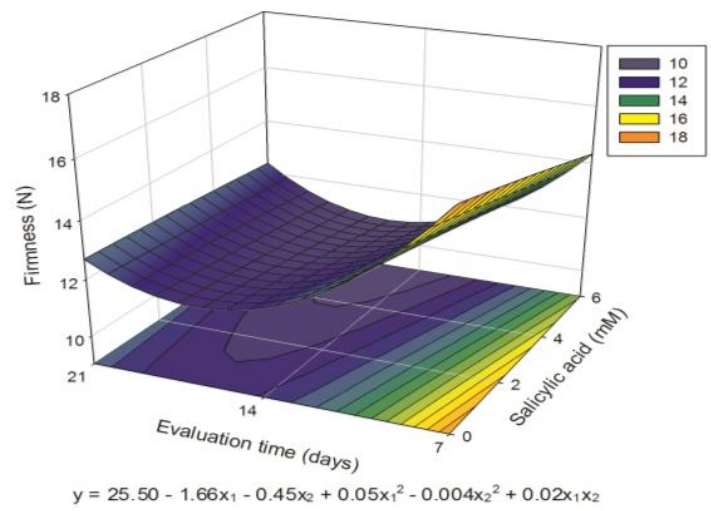

Fig 3. Graph of response surface of the relation among firmness, salicylic acid doses $(0,2,4$ and $6 \mathrm{mM})$ applied postharvest, storage periods $\left(7,14\right.$ and 21 days at $\left.1 \pm 1^{\circ} \mathrm{C}\right)$ and a 3 -day shelf life simulation $\left(25 \pm 5^{\circ} \mathrm{C}\right)$.UFPel, Pelotas, RS, Brazil.

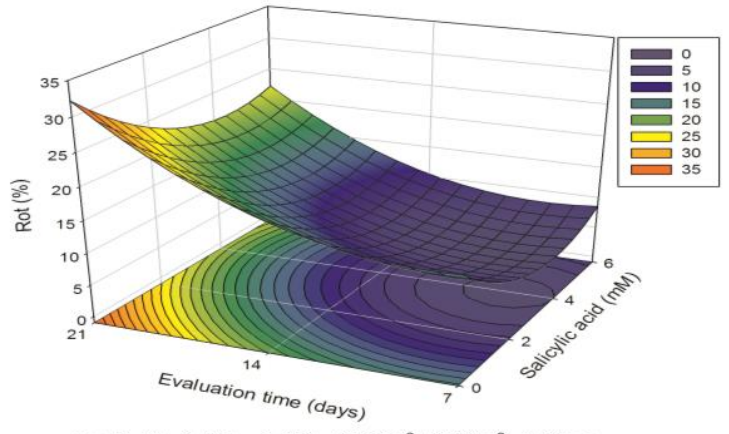

$y=21.52-1.59 x_{1}-4.45 x_{2}+0.10 x_{1}^{2}+0.60 x_{2}^{2}-0.04 x_{1} x_{2}$

Fig 4. Graph of response surface of the relation among rot percentage, salicylic acid doses $(0,2,4$ and $6 \mathrm{mM})$ applied postharvest, storage periods $\left(7,14\right.$ and 21 days at $\left.1 \pm 1^{\circ} \mathrm{C}\right)$ and a 3 -day shelf life simulation $\left(25 \pm 5^{\circ} \mathrm{C}\right)$.UFPel, Pelotas, RS, Brazil.

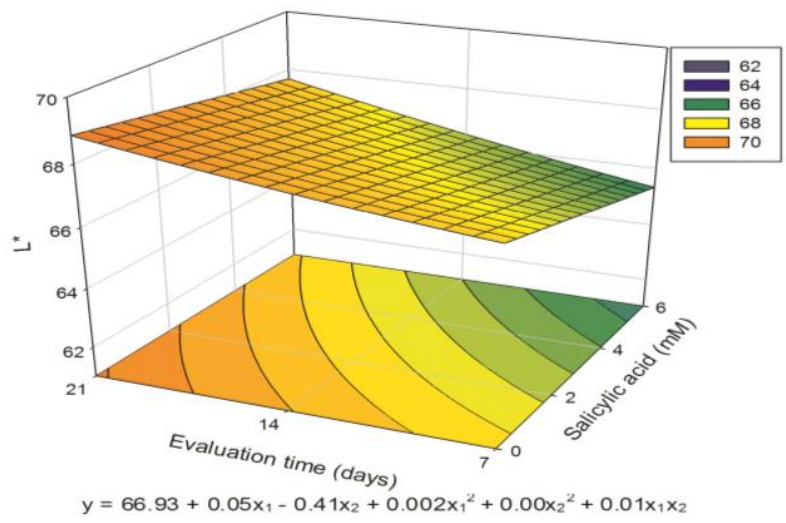

Fig 5. Graph of response surface of luminosity expressed as lightness (L) in relation to salicylic acid doses (0, 2, 4 and $6 \mathrm{mM})$ applied postharvest, storage periods $\left(7,14\right.$ and 21 days at $\left.1 \pm 1^{\circ} \mathrm{C}\right)$ and a 3 -day shelf life simulation $\left(25 \pm 5^{\circ} \mathrm{C}\right)$.UFPel, Pelotas, RS, Brazil. 


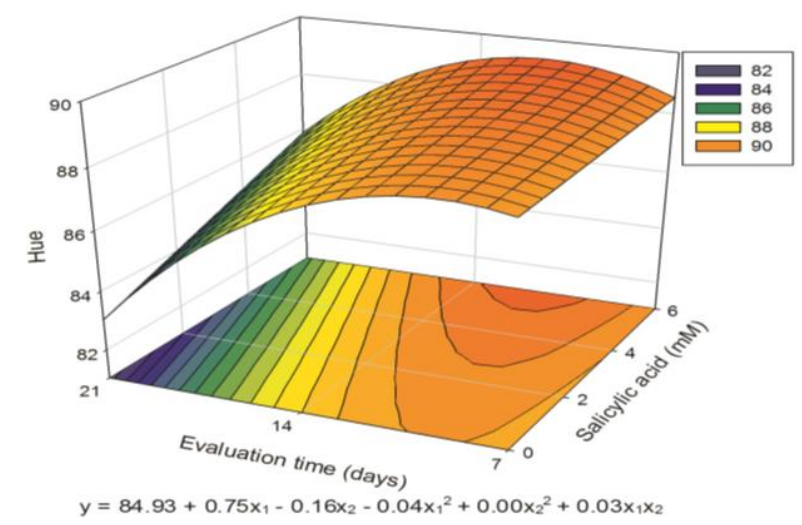

Fig 6. Graph of response surface of the surface color expressed as hue in relation to salicylic acid doses $(0,2,4$ and $6 \mathrm{mM})$ applied postharvest, storage periods $\left(7,14\right.$ and 21 days at $\left.1 \pm 1^{\circ} \mathrm{C}\right)$ and a 3 -day shelf life simulation $\left(25 \pm 5^{\circ} \mathrm{C}\right) . \mathrm{UFPel}$, Pelotas, RS, Brazil.

ammonialyase in the route of shikimic acid (Mazaro et al., 2015).

Studies of sensory analyses of fruits treated with SA postharvest show - in the hedonic scale - that consumers accept them well in terms of appearance, aroma, taste and sweetness (Fattahi et al., 2010), besides considering them safe (Geransayeh et al., 2015).

\section{Materials and Methods}

The postharvest experiment was carried out in the fruit laboratory at the Universidade Federal de Pelotas, located in Pelotas, RS, Brazil. Fruits were picked at the Centro Agropecuário (3152'00 "S, 5221'24" W and $13.34 \mathrm{~m}$ altitude) from 'Jubileu' peach trees on 15-year-old 'Capdeboscq' rootstocks. Orchard density is 1.481 plants/ha' ${ }^{1}$, with $4.5 \mathrm{~m} \times 1.5 \mathrm{~m}$ spacing, shaped as open vases. Fruits are picked in agreement with a scale of ripening degrees described by Cantillano (2014), in which about $75 \%$ of plants reach the ideal fruit ripening degree.

The experimental design was thoroughly randomized in double factorial with four repetitions. Emission control measures of storage output were used and divided into four repetitions of 20 fruits each, per treatment per period.

Picked fruits were taken to the laboratory, washed with distilled water and driedby forced-air ventilation. Then, they were pre-cooled at about $15^{\circ} \mathrm{C}$ and an evaluation of fruit characterization with no zero day was carried out.

The SA solution comprised the Synth ${ }^{\circledR}$ reagent, whose molecular formula is $\mathrm{C}_{7} \mathrm{H}_{6} \mathrm{O}_{3}$, previously solubilized in $20 \mathrm{~mL}$ ethyl alcohol and diluted in distilled water at 0, 2, 4 and 6 $\mathrm{mM}$. An application of the SA solution was done by a Guarani ${ }^{\circledR}$ backpack sprayer, with a fan spray nozzle and fine drops $(101-200 \mu)$, so as to reach about $2 \mathrm{~mL}$ solution per fruit, on average.

After the first application of the solution, the fruits underwent drying by forced-air ventilation. Then, they were packed in plastic boxes $(30 \times 30 \times 20 \mathrm{~cm})$ in the cold room at $1 \pm 1^{\circ} \mathrm{C}$ and relative humidity between 85 and $95 \%$, with electronic monitoring. Fruits were withdrawn from the cold room after 7,14 and 21 days and went through a 3-day shelf life simulation at $20 \pm 5^{\circ} \mathrm{C}$.

The following characteristics of peaches were analyzed: soluble solids, by refractometry, and results were expressed as oBrix; titratable acidity, measured by neutralization titration up to $\mathrm{pH} 8.1$, and results expressed as percentage of citric acid, both represented by the equation of the relation between soluble solids/titratable acidity; fresh weight loss, determined by the difference between the initial mass and the mass at the evaluation period, expressed as percentage; firmness, measured at two opposite spots of the equatorial region by a manual penetrometer with an 8 $\mathrm{mm}$ probing rod, and results expressed as $\mathrm{N}$; rot, determined by the number of fruits which had visual symptoms, and results expressed as percentage of infected fruits; and surface color, in the median of the fruit, measured by readings of coordinates $L^{*}, a^{*}$ and $b^{*}$, besides hue, or chromatic tone, represented by the tonality angle, calculated by the equation Hue $=\operatorname{tg}-1(b / a)$ (Zenebon et al., 2008).

Data were analyzed in terms of normality, homoscedasticity and residual independence by the ShapiroWilk test, the Hartley test and graphical analysis, respectively. Afterwards, data underwent analysis of variance by the F-test $(p \leq 0.05)$. The regression procedure of the response surface (PROC RSREG) for Windows, with the analysis of linear effects and quadratic and linear interactions of independent variables, was used (Freund and Littell, 1991).

The selection of the model was based on: (a) residue; (b) $p$ value ( $\mathrm{p} \leq 0.05$ ); (c) standard deviation; and (d)R2 and R2adj. Then, the second order polynomial equation for the data of the response variable was defined: $y=\beta 0+\Sigma \beta i x i+\Sigma \beta i i x i 2+$ $\Sigma \beta i j x i x j$, where $y$ is the response variable; $x i, x j$ are input variables which influence the response variable; $\beta 0$ is the interception; $\beta i$ is the linear effect; $\beta$ ii is the quadratic effect; and $\beta \mathrm{ij}$ is the interaction between $\mathrm{xi}$ and $\mathrm{xj}$.

Aiming at optimization, the analysis of canonical rotational surface to the additional response was used: the levels of the variables ( $x 1$, dose, $x 2$, time) (in the experimental interval) were determined for the response of every dependent variable under study. Optimization of the response functions happened when the response function (yk) was translated, from the origin to the stationary points $(x 0)$. The response function was maximum when all root functions had negative values and minimum, when all roots had positive values. If any root function had positive and negative values, a saddle point was characterized (Myers, 1971; Khuri and Cornell, 1989). Correlations among dependent variables of this study were analyzed by the Pearson correlation coefficient. 


\section{Conclusion}

The salicylic acid dose of $2.74 \mathrm{mM}$ applied postharvest to 'Jubileu' peaches, which were stored for 12.89 days, represents all means of factors evaluated by this experiment. Higher doses were effective to mitigate weight loss and rot incidence. All treatments with SA had good results regarding the maintenance of characteristics related to the useful life and postharvest quality of the fruits.

\section{Acknowledgements}

The authors thank Mr. José Carlos Fachinello for his guidance, Capes, for the scholarships and Embrapa, for its supporting research.

\section{References}

Asghari M, Aghdam MS (2010) Impact of salicylic acid on postharvest physiology of horticultural crops. Trends Food Sci Technol. 21(9): 502-509.

Belitz HD, Grosch W (2004) Food chemistry. New York: Springer Verlag, 774p.

Borsatti FC, Mazaro SM, Danner MA, Nava GA, Dalacosta NL (2015) Indução de resistência a qualidade pós-colheita de amora-preta tratada com ácido salicílico. Rev Bras Frutic. 37(2):318-326.

Brackmann A, Sestari I, Steffens CA, Giehl RFH (2007) Indução da perda de massa da matéria fresca e a ocorrência de distúrbios fisiológicos em maçãs 'Royal Gala' durante o armazenamento em atmosfera controlada. Rev Bras Armaz. 32(2):87-92.

Cantillano RFF (2014) Manejo e conservação pós-colheita: fisiologia e tecnologia cap. 20 p.559-603. In: Raseira MCB, Pereira JFM, Carvalho FLC Pessegueiro, Embrapa, 776p.

Comiotto A, Fachinello JC, Hoffmann A, Machado NP, Galarça SP, Betemps DL (2012) Vigor, floração, produção e qualidade de pêssegos 'Chimarrita' e 'Maciel' em função de diferentes porta-enxertos. Ciênc Rural, 42(5): 788-794.

Fachinello JC, Pasa MS, Schmtiz JD, Betemps BL (2011) Situação e perspectivas da fruticultura de clima temperado no Brasil. Rev Bras Frutic. e:109-120.

FAO (2016) Food and agriculture organization of the united Nations. Faostat: Production crops. Disponível em <http://faostat3.fao.org/browse/Q/*/E > Acessed in: June.10.2016.

Fattahi J, Fifaii R, Babri M (2010) Postharvest quality of Kiwi fruit (Actinidia deliciosa cv. Hayward) affected by prestorage application of salicylic acid. J Hortic Biol Environ. 1(2):175-186.

Freund RJ, Littell RC (1991) SAS system for regression. SAS Institute, Cary, North Carolina.

Geransayeh M, Sepahvand S, Abdossi V, Zarrinnia V, Nezhad RA (2015) A comparative study on the effects of thymol, methyl jasmonate and salicylic acid on postharvest life and maintaining quality of strawberry fruit cv. 'Gaviota'. J Biol Nat. 2(4):127-134.

Ghaderi N, Normohammadi S, Javadi T (2015) Morphophysiological responses of Strawberry (Fragaria $\mathrm{x}$ ananassa) to exogenous salicylic acid application under drought stress. J Agr Sci Tech. 17(1):167-178.
Hadian-Deljou M, Esna-Ashari M, Sarikhani H (2017) Effest of pre and post-harvest salicylic acid treatments on quality and antioxidant properties of 'Red delicious' apples during cold storage. Adv Hortic Sci. 31(1): 31-38.

Hall D, Kim KH, Luca V (2011) Molecular cloning and biochemical characterization of three Concord grape (Vitis labrusca) flavonol 7-O-glucosyltransferases. Planta. 234(1):1201-1214.

Infante R, Contador L, Rubio P, Mesa K, Meneses C (2011) Non-destructive monitoring of flesh softening in the blackskinned Japanese plums 'Angeleno' and 'Autumn beaut' on-tree and postharvest. Postharvest Biol Technol. 61: 3540.

Khademi Z, Ershadi A (2013) Postharvest application of salicylic acid improves storability of peach (Prunuspersica cv. Elberta) fruits. Int J Agric Crop Sci. 56: 651-655.

Khuri Al, Cornell JA (1989) Response Surfaces: Designs and Analyses, Marcel Dekker, New York.

Madail JC (2014) Economia do Pêssego no Brasil. c. 28; p. 687-704. In: Raseira, M. C. B.; Pereira, J. F.; Carvalho, F. L. C. Pessegueiro. Embrapa, 776p.

Mazaro SM, Borsatti FC, Dalacosta NL, Lewandowski A, Danner MA, Busso C, Junior AW (2015) Salicylic acid operates in maintenance of post-harvest quality acerolas. Agrária. 10(4):512-517.

Myers RH (1971). Response Surface Methodology, Allyn and Bacon, Boston.

Oliveira MC, Pio R, Ramos JD, Alvarenga AA, Santos VA, Fante C (2011) Seleção de ameixeiras promissoras para a Serra da Mantiqueira. Ceres. 58(4):531- 535.

Quaglia M, Ederli L, Pasqualini S, Zazzerini A (2011) Biological control agentes and chemicas induceres of resistance for postharvest control of Penicillium expansum link. on apple fruit. Postharvest Biol Technol. 59(3):307-315.

Salari N, Baharaminejad A, Afsharmanesh G, Khajehpour G (2012) Effect of salicylic acid on post-harvest quantitative and qualitative traits of strawberry cultivars. Adv Environ Biol. 7(1):94-99.

Serrano M, Wang B, Aryal B, Garcion C, Abou-Mansour E, Heck S, Geisler M, Mauch F, Nawrath C, Métraux JP (2013) Export of salicylic acid from the chloroplast requires the multidrug ant toxin extrusion-like transporter EDS5. Plant Physiol. 162: 1815-1821.

Supapvanich S, Promyou S (2013) Efficiency of salicylic acid application on postharvest perishable crops. 339-355. In: Hayat S, Ahmad A, Alyemeni MN. Salicylic acid, Plant Growth and Development, 389p.

Tareen MJ, Abbasi NA, Hafiz IA (2012) Effect of salicylic acid treatments on storage life of peach fruits cv. 'flordaking'. Pak J Bot. 44(1): 119-124.

Weber D, Eloy J, Beskow TG, Barbosa MM, Saavedra J, Fachinello JC (2012) Ácido salicílico e refrigeração na conservação de maracujás. Rev. Iber. Tecnol Postcosecha. 13(2):123-129.

Yang Z, Cao S, Cai Y, Zheng Y (2011) Combination of salicylic acid and ultrasound to control postharvest blue mold caused by Penicillium expansum in peach fruit. Innov Food Sci Emerg Technol. 12: 310- 314.

Zenebon O, Pascuet NS, Tiglea P (2008) Métodos físicoquímicos para análise de alimentos. 4. ed. São Paulo: Instituto Adolfo Lutz, 1, 1020p. 